\title{
Citral chemotype of the Lippia alba essential oil as an additive in simulated transport with different loading densities of tambaqui juveniles
}

\section{Hugo Napoleão Pereira da Silva ${ }^{* *}$ (D) Rodrigo Numeriano de Souza ${ }^{2}$ Elen Monique de Oliveira Sousa ${ }^{2}$ Rosa Helena Veras Mourão ${ }^{3}$ Bernardo Baldisserotto $^{4}$ Lenise Vargas Flores da Silva ${ }^{2}$}

${ }^{1}$ Programa de Pós-graduação em Biodiversidade Animal, Departamento de Fisiologia e Farmacologia, Universidade Federal de Santa Maria (UFSM), 97105-900, Santa Maria, RS, Brasil. E-mail: hugoufpa@hotmail.com. *Corresponding author.

${ }^{2}$ Programa de Pós-graduação em Aquicultura, Laboratório de Peixes Ornamentais Marinhos (LAPOM), Universidade Federal de Santa Catarina, Florianópolis, SC, Brasil.

${ }^{3}$ Laboratório de Bioprospecção e Biologia Experimental, Instituto de Saúde Coletiva (ISCO), Universidade Federal do Oeste do Pará (UFOPA), Santarém, Pará, Brasil.

${ }^{4}$ Departamento de Fisiologia e Farmacologia, Universidade Federal de Santa Maria (UFSM), Santa Maria, RS, Brasil.

ABSTRACT: The objective of this study was to evaluate the efficacy of the citral chemotype of Lippia alba essential oil (EOLA) as an additive in a simulated transport with different loading densities of tambaqui (Colossoma macropomum) juveniles. Simulated transport of tambaqui juveniles at three loading densities (30, 60 and 90 fish/L) was carried out either with only water (WC) or $20 \mu L . L^{-1}$ EOLA. Dissolved oxygen levels, $\mathrm{PH}$, conductivity and temperature of the water were measured at the beginning and end of the simulated transport. Treatment with EOLA did not change survival or dissolved oxygen levels at the end of simulation. The pH of the water at the end of simulation with EOLA was lower than in that of WC but did not change with loading density. Water conductivity increased with loading density; however, it was lower in the groups with EOLA. The addition of EOLA can be useful in long-term transportation at high loading densities, but further studies related to tambaqui physiology are required.

Key word: fish transportation, additive, water quality, Lippia alba, oxygen, conductivity.

Óleo essencial de Lippia alba quimiotipo citral como aditivo em transporte simulado de juvenis de Tambaqui com diferentes densidades

RESUMO: $O$ objetivo deste estudo foi avaliar a eficácia do óleo essencial de Lippia alba quimiotipo citral (EOLA) como aditivo em transporte simulado com diferentes densidades de carga de juvenis de tambaqui (Colossoma macropomum). O transporte simulado de juvenis de tambaqui em três densidades de carga (30, 60 e 90 peixes / L) foi realizado apenas com água (WC) ou $20 \mu L . L-1$ EOLA. Níveis de oxigênio dissolvido, $\mathrm{pH}$, condutividade e temperatura da água foram medidos no início e no final do transporte simulado. O tratamento com EOLA não alterou a sobrevivência ou os niveis de oxigênio dissolvido no final da simulação. O pH da água no final da simulação com o EOLA foi menor que o do WC, mas não mudou com a densidade de carga. A condutividade da água aumentou com a densidade de carga, no entanto foi menor nos grupos com EOLA. A adição de EOLA pode ser útil no transporte de longo prazo em altas densidades de carga, mas são necessários mais estudos relacionados à fisiologia do tambaqui.

Palavras-chave: transporte de peixes, aditivo, qualidade de água, Lippia alba, oxigênio, condutividade.

The discovery of natural substances that can be used as sedatives and/or anaesthetics in aquaculture is increasing (HOSEINI et al., 2018). Among these natural substances that have been researched, the essential oil of Lippia alba (EOLA) is one of the most studied in freshwater fish such as Rhamdia quelen (CUNHA et al., 2010), Colossoma macropomum (BATISTA et al., 2018;
MAIA et al., 2019) and Oreochromis niloticus (HOHLENWERGER et al., 2016).

The plant Lippia alba is widely found from north to south Brazil and has several chemotypes: linalool, citral, limonene and carvone, which also vary qualitatively and quantitatively according to geographic and climatic factors (AGUIAR et al., 2008). The linalool chemotype of the EOLA showed 
promising results as a sedative for fish transport (SOUZA et al., 2019), but the effect of the citral chemotype as a sedative was only observed in $R$. quelen (SOUZA et al., 2019; SOUZA et al., 2018).

The tambaqui (Colossoma macropomum) is distributed by the rivers of the Amazon and Orinoco basin, and has a meat that is appreciated by the local population. Among the characteristics that make the species suitable for farming are their ability to adapt to environmental changes and demonstrate good feed acceptance, good feed conversion and rapid growth (VALLADÃO et al., 2018). Therefore, the objective of this study was to evaluate the efficacy of the citral chemotype of EOLA as an additive in the simulated transport of tambaqui juveniles at different loading densities.

A total of 1080 tambaqui juveniles (1.12 $\pm 0.28 \mathrm{~g}$ ) were used in the simulated transport, at loading densities of 30 (D30: $33.60 \pm 9.40$ g.L.- ${ }^{-1}$ ), 60 (D60: $67.20 \pm 16.8$ g.L $\mathrm{L}^{-1}$ ) and 90 (D90: 100.8 \pm 25.2 g. $\left.\mathrm{L}^{-1}\right)$ fish/L (three replicates each). Juveniles were not feed for 24 hours. The simulated transport was carried out for $17 \mathrm{~h}, 26.6-27.1^{\circ} \mathrm{C}$, at the UAGRO Fish Production Station - Santa Rosa / SEDAp - SantarémPA, following the protocol of Silva et al. (2017). There were two treatments: EOLA at $20 \mu \mathrm{L} . \mathrm{L}^{-1}$ (diluted in ethanol at the ratio of $1: 10$ ), which corresponds to $10 \%$ of the lowest effective concentration for deep anaesthesia in tambaqui (BATISTA et al., 2018; SILVA et al., 2019) and water only (control - WC). Each experimental unit was composed of a plastic bag of total volume $7 \mathrm{~L}$, containing $1 \mathrm{~L}$ of water and $2 / 3$ of the complete volume with pure oxygen. Temperature, $\mathrm{pH}$, dissolved oxygen and conductivity levels were measured using a YSI multiparameter apparatus, before and after transport simulation. After, juveniles were transferred to a $7 \mathrm{~L}$ plastic container with continuously aerated water and maintained for $24 \mathrm{~h}$ for verification of survival.

The extraction and chemical characterisation of EOLA was carried out as described by SOUZA et al. (2017). The data were submitted to the Levene test to evaluate homoscedasticity. As data presented homogenous variances, two-way analysis of variance was followed by the Tukey test for mean comparison $(\mathrm{P}<0.05)$ using Sigma Plot software v.11. The experiment was approved by the Ethical Committee of Pará State University - Brazil, under registration no. 042-2012.

The results showed that citral was present as the main compound in EOLA (table 1). Treatments did not change survival or dissolved oxygen levels at the end of simulation. There was an increase in $\mathrm{pH}$ after $17 \mathrm{~h}$ of transport in both treatments; however, the addition of $20 \mu \mathrm{L} . \mathrm{L}^{-1}$ EOLA reduced the $\mathrm{pH}$ of the water as compared to the respective control groups. There was no effect of loading density on water $\mathrm{pH}$. There was an increase in conductivity with increasing loading density for both treatments, but conductivity was lower in the water of fish exposed to $20 \mu \mathrm{L}$. L ${ }^{-1}$ EOLA at densities of 60 and 90 fish / L (Table 2).

The citral chemotype of EOLA is effective as a sedative and anaesthetic in tambaqui (SILVA et al., 2019) and in the silver catfish, Rhamdia quelen (CUNHA et al., 2010), but further studies with the latter species demonstrated that it induces more side effects that the linalool chemotype (SOUZA et al., 2018). However, SILVA et al. (2017) verified an improvement in the physical and chemical parameters of the water of transport with the use of the L. alba hydrolate (citral chemotype).

Table 1 - Main compounds of the Lippia alba essential oil.

\begin{tabular}{lccc}
\hline Compounds & $\%$ & IRcal & IRLi \\
\hline Citral & 54.256 & 1270 & 1267 \\
Limonene & 6.148 & 1026 & 10292 \\
E-geraniol & 5.322 & 1256 & 12531 \\
Bicyclogermacrene & 3.72 & 1495 & 15001 \\
Z-geraniol & 3.566 & 1229 & 12301 \\
$\gamma$-terpinene & 3.164 & 1058 & 10601 \\
Elemol & 3.151 & 1549 & 15501 \\
$\gamma$-muurolene & 2.455 & 1476 & 14801 \\
\hline
\end{tabular}

IRcal index retention calculated; IRLi indexretention library. 
Citral chemotype of the Lippia alba essential oil as an additive in simulated transport with different loading densities of tambaqui juveniles.

Table 2 - Dissolved oxygen $\left(\mathrm{mg} . \mathrm{L}^{-1}\right)$, electrical conductivity $\left(\mu \mathrm{S} . \mathrm{cm}^{-1}\right)$, temperature $\left({ }^{\circ} \mathrm{C}\right)$ and $\mathrm{pH}$, after $17 \mathrm{~h}$ transport simulations of tambaqui juveniles. Load densities (D) of 30, 60 and 90 fish $\mathrm{L}^{-1}$ were tested in combination with EOLA concentrations of 20 $\mu \mathrm{L} . \mathrm{L}^{-1}$, and water was used as the control (WC).

\begin{tabular}{|c|c|c|c|c|}
\hline & Before & D30 & D60 & D90 \\
\hline WC & $6.16 \pm 0.01^{\mathrm{Aa}}$ & $5.19 \pm 2.13^{\mathrm{Aa}}$ & $3.97 \pm 1.04^{\mathrm{Aa}}$ & $3.58 \pm 0.73^{\mathrm{Aa}}$ \\
\hline EOLA $20 \mu \mathrm{L}$ & $6.25 \pm 0.00^{\mathrm{Aa}}$ & $4.87 \pm 0.46^{\mathrm{Aa}}$ & $2.55 \pm 0.79^{\mathrm{Aa}}$ & $3.01 \pm 0.75^{\mathrm{Aa}}$ \\
\hline \multicolumn{5}{|c|}{ 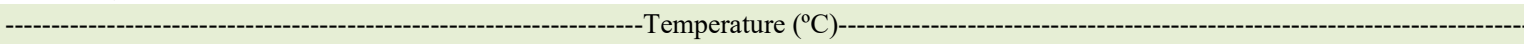 } \\
\hline WC & $28.85 \pm 0.07^{\mathrm{Aa}}$ & $26.76 \pm 0.05^{\mathrm{Ba}}$ & $26.66 \pm 0.05^{\mathrm{BCa}}$ & $26.63 \pm 0.05^{\mathrm{Ca}}$ \\
\hline EOLA $20 \mu \mathrm{L}$ & $28.8 \pm 0.00^{\mathrm{Aa}}$ & $27.00 \pm 0.00^{\mathrm{Bb}}$ & $27.10 \pm 0.00^{\mathrm{Bb}}$ & $27.10 \pm 0.00^{\mathrm{Bb}}$ \\
\hline \multicolumn{5}{|c|}{ 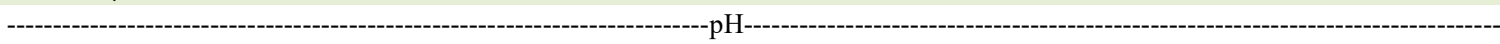 } \\
\hline WC & $5.40 \pm 0.35^{\mathrm{Aa}}$ & $6.00 \pm 0.00^{\mathrm{Ba}}$ & $6.13 \pm 0.11^{\mathrm{Ba}}$ & $6.16 \pm 0.05^{\mathrm{Ba}}$ \\
\hline EOLA $20 \mu \mathrm{L}$ & $5.27 \pm 0.10^{\mathrm{Aa}}$ & $5.83 \pm 0.05^{\mathrm{Ba}}$ & $5.83 \pm 0.05^{\mathrm{Bb}}$ & $5.96 \pm 0.05^{\mathrm{Bb}}$ \\
\hline \multicolumn{5}{|c|}{ 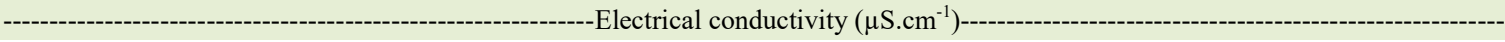 } \\
\hline WC & $10.90 \pm 0.48^{\mathrm{Aa}}$ & $154.46 \pm 10.69^{\mathrm{Aa}}$ & $346.03 \pm 12.80^{\mathrm{Ba}}$ & $435.20 \pm 16.41^{\mathrm{Ca}}$ \\
\hline EOLA $20 \mu \mathrm{L}$ & $10.90 \pm 0.26^{\mathrm{Aa}}$ & $153.63 \pm 8.56^{\mathrm{Aa}}$ & $263.56 \pm 6.53^{\mathrm{Bb}}$ & $397.10 \pm 42.78^{\mathrm{Cb}}$ \\
\hline
\end{tabular}

Superscripted lower-case letters indicate significant differences between EOLA concentrations (rows) for each load density (column). Superscripted capital letters indicate significant differences between load densities for each EOLA concentration by ANOVA TWO WAY, Tukey test $(\mathrm{P}<0.05)$.

In this study, we reported that the use of EOLA in the water during transport was effective only at higher loading densities (60 and 90 fish / $\mathrm{L})$, reducing the increase in conductivity, which demonstrated a lower level of ion loss by the fish. The same pattern of results was observed by SILVA et al. (2017) with $L$. alba hydrolate for the same species and BECKER et al. (2012) with the linalool chemotype of EOLA for silver catfish.

Results regarding conductivity suggested that the citral chemotype of EOLA may improve the quality of the transport water for tambaqui. However, further studies related to the effects of EOLA on biochemical and physiological parameters are necessary for a better understanding of the effects of this essential oil.

\section{ACKNOWLEDGEMENTS}

This study was supported by INCT-ADAPTA 2 (Fundação de Amparo à Pesquisa no Amazonas (FAPEAM) and Conselho Nacional de Desenvolvimento Tecnológico (CNPq) and Coordenação de Aperfeiçoamento de Pessoal de Nível Superior (CAPES) Pró Amazônia. We thank SEDAP Santarém PA for experimental logistical support.

\section{BIOETHICS AND BIOSSECURITY COMMITTEE APPROVAL}

This research was approved by the Ethical Committee of Pará State University - Brazil, under registration no. 042-2012.

\section{DECLARATION OF CONFLICT OF INTERESTS}

The authors declare no conflict of interest. The founding sponsors had no role in the design of the study; in the collection, analyses, or interpretation of data; in the writing of the manuscript, and in the decision to publish the results.

\section{AUTHORS' CONTRIBUTIONS}

All authors contributed equally for the conception and writing of the manuscript. All authors critically revised the manuscript and approved of the final version.

\section{REFERENCES}

AGUIAR, J. S. et al. Antimicrobial activity of Lippia alba (Mill.) N. E. Brown (Verbenaceae). Revista Brasileira de Farmacognosia, v.18: p.436-440, 2008. Available from: <http:// www.scielo.br/scielo.php? script $=$ sci_arttext\&pid $=$ S0102695X2008000300018\&nrm=iso>. Accessed: Aug. 27, 2019.

BATISTA, E. S. et al. Lippia alba essential oil as anesthetic for tambaqui. Aquaculture, v.495: p.545-549, 2018. Available from: <http://www.sciencedirect.com/science/article/pii/ S0044848618306690>. Accessed: Jul. 12, 2019. doi: 10.1016/j. aquaculture.2018.06.040.

BECKER, A. G. et al. Transportation of silver catfish, Rhamdia quelen, in water with eugenol and the essential oil of Lippia alba. Fish Physiology and Biochemistry, v.38: p.789-796, 2012. Available from: <http://dx.doi.org/10.1007/s10695-011-9562-4>. Accessed: Jul. 12, 2019. doi: 10.1007/s10695-011-9562-4. 
CUNHA, M. A. et al. Essential oil of Lippia alba: A new anesthetic for silver catfish, Rhamdia quelen. Aquaculture, v.306: p.403-406, 2010. Available from: <http://www.sciencedirect.com/science/ article/pii/S0044848610003790 >. Accessed: Apr. 1, 2019. doi 10.1016/j.aquaculture.2010.06.014.

HOHLENWERGER, J. C. et al. Could the essential oil of Lippia alba provide a readily available and cost-effective anaesthetic for Nile tilapia (Oreochromis niloticus)? Marine and Freshwater Behaviour and Physiology, p.1-8, 2016. Available from: $<$ https://www.tandfonline. $\mathrm{com} / \mathrm{doi} / \mathrm{abs} / 10.1080 / 10236244.2015 .1123869$ ?journalCode $=$ gm fw20>. Accessed: Apr. 1, 2019. doi: 10.1080/10236244.2015.1123869.

HOSEINI, S. M. et al. Application of herbal anaesthetics in aquaculture. Reviews in Aquaculture, v.0: 2018. Available from: $<$ https://doi.org/10.1111/raq.12245>. Accessed: Jul. 14, 2019. doi: 10.1111/raq. 12245

MAIA, J. L. S. et al. Hydrolate toxicity of Lippia alba (Mill.) N. E. Brown (Verbenaceae) in juvenile tambaqui (Colossoma macropomum) and its potential anaesthetic properties. Aquaculture, v.503: p.367-372, 2019. Available from: <http:// www.sciencedirect.com/science/article/pii/S0044848618301595>. Accessed: Apr. 26, 2019. doi: 10.1016/j.aquaculture.2018.11.058.

SILVA, H. N. P. et al. Anesthetic potential of the essential oils of Lippia alba and Lippia origanoides in Tambaqui juveniles/ Potencial anestesico do oleo essencial de Lippia Alba e Lippia origanoides em juvenis de Tambaqui. Ciência Rural, v.49: 2019. Available from: <https://link.gale.com/apps/doc/A597515205/ AONE? $\mathrm{u}=$ ufsm br\&sid $=$ AONE $\&$ xid $=863336 \mathrm{e} 8>$. Accessed: Sep. 19, 2019. doi: $10.1590 / 0103-8478$ cr20181059.
SILVA, H. N. P. et al. Lippia alba (Verbenaceae) hydrolate as sedative of tambaqui (Colossoma macropomum) juveniles in simulated transport conditions. Aquaculture Research, 2017. Available from: <https://onlinelibrary.wiley.com/ doi/abs/10.1111/are.13441>. Accessed: Jul. 12, 2019. doi: 10.1111/are. 13441

SOUZA, C. D. F. et al. Essential oils as stress-reducing agents for fish aquaculture: A Review. Frontiers in Physiology, v.10: 2019. Available from: <https://www.frontiersin.org/article/10.3389/ fphys.2019.00785>. Accessed: Aug. 27, 2019. doi: 10.3389/ fphys.2019.00785.

SOUZA, C. D. F. et al. Physiological responses of Rhamdia quelen (Siluriformes: Heptapteridae) to anesthesia with essential oils from two different chemotypes of Lippia alba. Neotropical Ichthyology, v.15: 2017. Available from: <http:// www.scielo.br/scielo.php? script $=$ sci arttext\&pid $=$ S 167962252017000100203\&nrm=iso >. Accessed: Jul. 12, 2019.

SOUZA, C. F. et al. Citral and linalool chemotypes of Lippia alba essential oil as anesthetics for fish: a detailed physiological analysis of side effects during anesthetic recovery in silver catfish (Rhamdia quelem). Fish Physiology and Biochemistry, v.44: p.21-34, 2018. Available from: <https://doi.org/10.1007/ s10695-017-0410-z>. Accessed: Sep. 14, 2019. doi: 10.1007/ s10695-017-0410-z.

VALLADÃO, G. M. R. et al. South American fish for continental aquaculture. Reviews in Aquaculture, v.10: p.351-369, 2018. Available from: <https://onlinelibrary.wiley.com/doi/abs/10.1111/ raq.12164>. Accessed: Jul. 12, 2019. doi: 10.1111/raq.12164. 